\title{
Performance responses of lambs of various ages to Italian ryegrass (Lolium multiflorum) fertilized with various levels of nitrogen
}

\author{
J. F. de Villiers ${ }^{\#}$ and J. B. J. van Ryssen ${ }^{1}$ \\ KwaZulu-Natal Department of Agriculture and Environmental Affairs, Private Bag X9059, \\ Pietermaritzburg 3200, South Africa; ${ }^{1}$ Department of Animal and Wildlife Sciences, University of Pretoria, Pretoria \\ 0002, South Africa.
}

\begin{abstract}
Italian ryegrass (Lolium multiflorum cv. Midmar) is often fertilized with high levels of nitrogen $(\mathrm{N})$ in order to ensure maximum dry matter (DM) yields. This practice also increases the $\mathrm{N}$ content of herbage. This study was conducted to determine whether differences in the nitrogen $(\mathrm{N})$ content of Italian ryegrass would have an effect on the performance of South African Mutton Merino lambs. Fertilizer levels of 100, $200,400,600$ or $800 \mathrm{~kg} \mathrm{~N} / \mathrm{ha}$ were applied to the pastures in order to produce herbage containing varying concentrations of $\mathrm{N}$. Nitrogen fertilization increased the total $\mathrm{N}$ and nitrate- $\mathrm{N}$ in the plant material and decreased non-structural carbohydrate concentrations. An increase in rumen ammonia-N concentration with increasing pasture $\mathrm{N}$ concentration was observed in twelve and four-month-old lambs. A quadratic relationship was found to exist between the $\mathrm{N}$ content of ryegrass and DM intake for twelve-month-old lambs, and a negative linear relationship was observed for four-month-old lambs. A quadratic relationship was observed between the $\mathrm{N}$ content of ryegrass and average daily gain for lambs of both age groups. The equations derived in this study illustrate the potentially negative effects of high concentrations of $\mathrm{N}$ and nitrate- $\mathrm{N}$ in Italian ryegrass on intake and growth rate of lambs.
\end{abstract}

Keywords: average daily gain, dry matter intake, Italian ryegrass, lambs, nitrogen, nitrate-nitrogen

${ }^{\#}$ Author to whom correspondence should be addressed. E-mail: devilliersj@cedara.kzntl.gov.za

\section{Introduction}

Italian ryegrass (Lolium multiflorum cv. Midmar) is a pasture species utilized largely for its ability to provide winter grazing for sheep in semi-intensive and intensive livestock production systems. The production of Italian ryegrass in a sub-tropical environment requires intensive management inputs in terms of fertilization and irrigation to ensure maximum dry matter (DM) yields. Nitrogen (N) fertilization not only influences the pasture DM yield, but also influences herbage composition (Eckard, 1986). Eckard (1990) reported that the DM yield of Italian ryegrass approached a maximum when herbage $\mathrm{N}$ concentrations were between 3.2 and $3.5 \%$ (20-22\% CP). N applications exceeding $350 \mathrm{~kg} \mathrm{~N} / \mathrm{ha} /$ year appeared to be in excess of the growth requirements of the grass (Eckard, 1989). Ruminant diets should contain a minimum of $1.4 \% \mathrm{~N}$ for maintenance and $2.3 \%$ for high production rates, but concentrations in excess of $3 \% \mathrm{~N}$ may not be conducive to optimum animal production (Wilman, 1970). The performance of lambs grazing ryegrass is often disappointing. Possible reasons for this are high moisture concentrations in plant material (Meissner $e t$ al., 1992) and extensive hydrolysis of highly soluble and degradable proteins that often result in insufficient protein reaching the small intestine (Aii \& Stobbs, 1980). This is of particular concern in the case of temperate pastures of high $\mathrm{N}$ content and is further aggravated by $\mathrm{N}$ fertilization (Meissner et al., 1993). The use of high $\mathrm{N}$ fertilization rates for cultivated pastures has increased the occurrence of metabolic disorders such as ammonia toxicity and nitrate poisoning, and has suppressed production (Hibbit, 1984). According to Coombe \& Hood (1980), negative effects on production include disturbances in mineral and vitamin metabolism and reduced rates of growth, reproduction and milk yield. Nitrogen in intensively fertilized Italian ryegrass pastures at an early stage of maturity (regrowth) is highly soluble and highly degradable in the rumen (Meissner et al., 1993; Van der Merwe, 1993). There are indications that $\mathrm{N}$ is lost as ammonia $\left(\mathrm{NH}_{3}\right)$ from the rumen when the forage $\mathrm{N}$ content exceeds 3\% (Meissner et al., 1993). Thomson et al. (1982) regarded the reduced supply of absorbed protein as a major limitation to the nutritional value of fresh or grazed grass and concluded that this restricted the performance of grazing ruminants, particularly growing and lactating animals. This study was conducted to investigate whether Italian ryegrass with a high $\mathrm{N}$ content due to high $\mathrm{N}$ fertilization levels would have a detrimental effect on the performance of lambs.

\section{Materials and Methods}

Italian ryegrass pasture was established in mid-February during two consecutive seasons on a one ha area of vlei land (Katspruit soil) at the Cedara Research Station $\left(29^{0} 32^{\prime} \mathrm{S} ; 30^{\circ} 17^{\prime} \mathrm{E}\right.$; altitude: $1075 \mathrm{~m}$; annual rainfall: $885 \pm 142 \mathrm{~mm}$ ). The plot was subdivided into 28 equal areas, each of which were divided into three 
sub-plots and allocated to one of three fertilizer treatments. The treatments consisted of three levels of $\mathrm{N}$ applied according to the recommendations of Eckard (1986) to result in herbage containing low, medium or high levels of N. Fertilizer levels of 200,400 and $600 \mathrm{~kg} \mathrm{~N} / \mathrm{ha}$ (low, medium and high respectively) were applied during the first season, and levels of 100, 400 and $800 \mathrm{~kg} \mathrm{~N} / \mathrm{ha}$ (low, medium and high respectively) were applied during the second season. Limestone ammonium nitrate (LAN; 28\% N) was used as fertilizer during the first season, with a top dressing of potassium chloride at a rate of $50 \mathrm{~kg} \mathrm{~K} / \mathrm{ha}$ in mid-August. During the second season, LAN and 1:0:1 $(18 \% \mathrm{~N}$ and $18 \% \mathrm{~K})$ were alternated every 28 days in six applications. The same sub-plots designated for the low, medium and high fertilizer levels during the first season were used during the second season. The pasture was irrigated to ensure an application of $25 \mathrm{~mm}$ of water per week. The 28 plots were cut in sequence, one per day. The appropriate amounts of $\mathrm{N}$ fertilizer were applied following cutting. This procedure thus simulated a four-week grazing cycle.

Fifteen four-month-old and fifteen twelve-month-old South African Mutton Merino wethers were used in each season. Mean initial live mass was $41.1 \pm 0.33 \mathrm{~kg}$ for the 12-month-old lambs and $25.2 \pm 0.51$ $\mathrm{kg}$ for the 4-month-old lambs (weaner lambs). The 12-month-old lambs represented the age at which sheep would typically graze ryegrass during the early part of the ryegrass season (April to July), and the newlyweaned lambs were used to simulate the age at which lambs would normally graze annual ryegrass in an autumn lambing system (i.e. during spring; August to November). The 12-month-old lambs were fed harvested ryegrass for seven weeks and the 4-month-old lambs were fed for 10 weeks in individual feeding pens with elevated slatted floors. The herbage was cut daily at approximately 07:00, chopped to $25 \mathrm{~mm}$ lengths in a hammer mill and accurately weighed for individual feeding twice daily at 09:30 and 14:00. Feed allocations were determined according to the herbage intake recorded during the previous day (allowing for a $20 \%$ refusal). Live mass was determined weekly before feeding. Water and feed were not withheld before weighing, except before the first and last weight measurements of the trials. The lambs had free access to fresh water and a mineral lick consisting of 50\% salt, 25\% bonemeal, and 25\% feedlime.

At the start of the trials the wool in the midrib area was clipped as close as possible to the skin. On the last day of each trial, an area of $100 \mathrm{~cm}^{2}$ was harvested from the previously shorn midrib area to determine wool growth. Wool samples were analysed for fibre diameter and clean yield percentage using standard methods proposed by the International Wool and Textile Organisation (IWTO).

Samples representative of the pasture fed to the animals and $10 \%$ sub-samples of orts were taken daily, dried in a forced-draught oven at $100{ }^{\circ} \mathrm{C}$ for $24 \mathrm{~h}$ and then milled. The samples were analysed for DM, $\mathrm{N}$ (macro-kjeldahl; AOAC, 1980), nitrate- $\mathrm{N}\left(\mathrm{NO}_{3}-\mathrm{N}\right)$ content (specific ion electrode method; Barker, 1974, Orion Research Inc., 1979), total non-structural carbohydrates (TNSC) (Marais, 1985) and acid detergent fibre (ADF) according to the procedure of Holst (1973) with decalin omitted as recommended by Van Soest \& Robertson (1980).

The lambs were used in digestibility studies (Bredon et al., 1961) five weeks after the commencement of feeding to determine in vivo digestible organic matter (IVDOM). Individual rumen fluid samples were taken from two animals per treatment for three consecutive days at the end of each digestion trial using a stomach tube and an electric vacuum pump. The first sample was taken immediately prior to feeding at 09:00, the next sample at 12:00, and thereafter at two-hourly intervals until 18:00. The rumen fluid $(5 \mathrm{ml})$ was then transferred to test-tubes containing hydrochloric acid $(5 \mathrm{ml})$ and immediately analysed for $\mathrm{NH}_{3}-\mathrm{N}$ (Weatherburn, 1967).

Data for chemical composition, digestibility, $\mathrm{NH}_{3}-\mathrm{N}$ concentration, $\mathrm{N}$-intake, DM-intake, ADG, wool growth and wool fibre diameter were subject to statistical analysis by least significant differences using Statgraphics (1988). Regression analysis was performed using the GENSTAT 5 statistical program (1993), to test relationships between animal performance data and chemical composition of the ryegrass. No clear trend was observed within seasons and data was pooled for statistical analysis.

\section{Results and Discussion}

The induction of differences in the chemical composition of ryegrass by the application of different levels of fertiliser was only partially successful; however, differences $(\mathrm{P}<0.05)$ were obtained for $\mathrm{N}(\mathrm{CP})$, $\mathrm{NO}_{3}-\mathrm{N}$ and TNSC (Table 1). The lack of consistent differences between treatments may be due to factors such as N contributions from the soil and varying climatic conditions (Dickson \& Macpherson, 1976; Wilson, 1981). The soluble $\mathrm{N}$ fraction, rate of degradation of the potentially degradable fraction and effective $\mathrm{N}$ degradability of herbage decreases with advancing stage of re-growth (Van der Merwe, 1993). Herbage $\mathrm{NO}_{3}-\mathrm{N}$ concentrations increased with increasing $\mathrm{N}$ fertilisation level and tend to peak two to three weeks after fertiliser application (Phipps, 1975). In this study a grazing cycle of 28-days was simulated and could also have contributed to the lack of clear differences between treatments. 
Table 1 Average chemical composition (DM basis), dry matter intake (g/day), $\mathrm{N}$ intake (g/day) and rumen ammonia-N concentrations $(\mathrm{mg} / 100 \mathrm{ml})$ for ryegrass fertilized with different levels of nitrogen over two seasons

\begin{tabular}{|c|c|c|c|c|c|}
\hline & \multicolumn{3}{|c|}{ N-fertilization level } & \multirow[b]{2}{*}{ s.e.m. } & \multirow[b]{2}{*}{$\mathrm{P}$} \\
\hline & $\begin{array}{c}\text { Low } \\
(100 \text { or } 200 \mathrm{~kg} \mathrm{~N} / \mathrm{ha}) \\
\end{array}$ & $\begin{array}{c}\text { Medium } \\
(400 \mathrm{~kg} \mathrm{~N} / \mathrm{ha}) \\
\end{array}$ & $\begin{array}{c}\text { High } \\
(600 \text { or } 800 \mathrm{~kg} \mathrm{~N} / \mathrm{ha}) \\
\end{array}$ & & \\
\hline \multicolumn{6}{|l|}{$\begin{array}{l}\text { April - July } \\
\text { 12-month-old lambs: }\end{array}$} \\
\hline $\mathrm{DM}(\%)$ & 14.8 & 14.2 & 14.2 & 0.190 & 0.30 \\
\hline $\mathrm{CP}(\%)$ & 21.3 & 22.4 & 24.3 & 0.54 & 0.09 \\
\hline $\mathrm{NO}_{3}-\mathrm{N}(\%)$ & $0.14^{\mathrm{a}}$ & $0.16^{\mathrm{a}}$ & $0.27^{\mathrm{b}}$ & 0.019 & 0.03 \\
\hline $\operatorname{TNSC}(\%)$ & 17.3 & 16.0 & 13.0 & 1.04 & 0.25 \\
\hline DMI (g/day) & 1544 & 1596 & 1558 & 27.1 & 0.72 \\
\hline \multicolumn{6}{|l|}{ Digestibility trial } \\
\hline DMI (g/day) & 1228 & 1450 & 1472 & 53.5 & 0.18 \\
\hline N\% of feed & $3.88^{\mathrm{a}}$ & $4.09^{\mathrm{a}, \mathrm{b}}$ & $4.41^{\mathrm{b}}$ & 0.079 & 0.062 \\
\hline $\operatorname{IVDOM}(\%)$ & 70.5 & 70.5 & 70.7 & 0.34 & 0.978 \\
\hline $\mathrm{N}$ intake (g/day) & 53.4 & 58.1 & 61.9 & 1.58 & 0.10 \\
\hline \multicolumn{6}{|c|}{$\underline{\text { Rumen ammonia concentrations }}$} \\
\hline $\mathrm{NH}_{3}-\mathrm{N}(\mathrm{mg} / 100 \mathrm{ml})$ & $20.1^{\mathrm{a}}$ & $24.3^{\mathrm{a}, \mathrm{b}}$ & $28.0^{\mathrm{b}}$ & 0.171 & 0.02 \\
\hline \multicolumn{6}{|l|}{$\begin{array}{l}\text { August - November } \\
\text { Weaner lambs: }\end{array}$} \\
\hline $\mathrm{DM}(\%)$ & 16.0 & 14.8 & 14.5 & 0.40 & 0.27 \\
\hline $\mathrm{CP}(\%)$ & $18.6^{\mathrm{a}}$ & $20.5^{\mathrm{a}}$ & $24.2^{\mathrm{b}}$ & 0.64 & 0.003 \\
\hline $\mathrm{NO}_{3} \mathrm{~N}(\%)$ & $0.24^{\mathrm{a}}$ & $0.27^{\mathrm{a}}$ & $0.46^{\mathrm{b}}$ & 0.30 & 0.007 \\
\hline $\operatorname{TNSC}(\%)$ & $12.7^{\mathrm{b}}$ & $10.0^{\mathrm{a}, \mathrm{b}}$ & $7.9^{\mathrm{a}}$ & 0.69 & 0.02 \\
\hline DMI (g/day) & 1047 & 1302 & 1163 & 46.3 & 0.09 \\
\hline \multicolumn{6}{|l|}{ Digestibility trial } \\
\hline DMI (g/day) & 1300 & 1273 & 1189 & 113.1 & 0.916 \\
\hline N\% of feed & $3.6^{\mathrm{a}}$ & $4.3^{\mathrm{b}}$ & $4.7^{\mathrm{c}}$ & 0.071 & 0.001 \\
\hline $\operatorname{IVDOM}(\%)$ & 70.3 & 70.3 & 68.4 & 0.674 & 0.431 \\
\hline $\mathrm{N}$ intake (g/day) & $30.4^{\mathrm{a}}$ & $41.9^{\mathrm{b}}$ & $45.0^{\mathrm{b}}$ & 1.71 & 0.002 \\
\hline \multicolumn{6}{|c|}{$\underline{\text { Rumen ammonia concentrations }}$} \\
\hline $\mathrm{NH}_{3}-\mathrm{N}(\mathrm{mg} / 100 \mathrm{ml})$ & $18.6^{\mathrm{a}}$ & $26.4^{\mathrm{ab}}$ & $35.7^{\mathrm{b}}$ & 2.67 & 0.06 \\
\hline
\end{tabular}

${ }^{\mathrm{a}, \mathrm{b}}$ Row means without common superscripts differ $(\mathrm{P}<0.05)$; TNSC: Total non-structural carbohydrates; IVDOM: In vivo digestible organic matter; DMI: dry matter intake; $\mathrm{NO}_{3} \mathrm{~N}$ : nitrate nitrogen; s.e.m.: standard error of the mean

Neither DM content nor dry matter intake of lambs were affected by treatment (Table 1). Holmes \& Lang (1963) found that DM intakes were similar for both herbages tested by them, even though the DM content of herbage from their high $\mathrm{N}$ fertilization treatment was consistently lower than that from their low $\mathrm{N}$ treatment ( $16.5 \%$ vs. $19.7 \%)$.

The increased levels of $\mathrm{N}$ fertilization caused an increase in the mean $\mathrm{NO}_{3}-\mathrm{N}$ concentrations of the 
herbage (Table 1). However, the mean $\mathrm{NO}_{3}-\mathrm{N}$ concentrations did not exceed the "safe limit" of $0.57-0.60 \%$ for ruminants (Coombe \& Hood, 1980; Deinum \& Sibma, 1980). The mean N concentrations of grass offered to both age groups and treatments were high (Table 1) and in excess of the requirements of sheep at all stages of production (ARC, 1985). The $\mathrm{N}$ requirement of a $40 \mathrm{~kg}$ castrated lamb is approximately 39 g/day (ARC, 1985). In comparison, the $\mathrm{N}$ intakes of the 12-month-old lambs were excessively high (Table 1). The requirement of a $30 \mathrm{~kg}$ lamb for a mass gain of $200 \mathrm{~g} /$ day is $31 \mathrm{~g} / \mathrm{day}$ (ARC, 1985). The $\mathrm{N}$ intake of all weaner lambs except those of the low $\mathrm{N}$-fertilization level treatment was in excess of requirements (Table 1).

A major concern when feeding pastures containing 1.9-4.0\% $\mathrm{N}$ is the poor utilization and wastage of plant protein by the animal (Waghorn \& Barry, 1987). Because $\mathrm{N}$ is lost from the rumen as $\mathrm{NH}_{3}$ at dietary concentrations in excess of $2.5 \% \mathrm{~N}$, the amino acid uptake from the small intestine may be limiting for temperate forages containing high concentrations of total and soluble $\mathrm{N}$ (Meissner et al., 1993). An increase in $\mathrm{NH}_{3}-\mathrm{N}$ concentrations was observed (Table 1) with increased concentrations of $\mathrm{N}$ in the pasture. Beever \& Siddons (1986) found that herbage with high CP concentrations (>20\%) and high CP degradation rates caused high rumen $\mathrm{NH}_{3}$ concentrations. The rumen $\mathrm{NH}_{3}-\mathrm{N}$ concentrations for the medium and high fertilization treatment levels in this study exceeded the value of between 2 and $23.5 \mathrm{mg} \mathrm{NH} 3$ per $100 \mathrm{ml}$ rumen fluid which is accepted as the ideal concentration for optimal microbial synthesis (Mehrez et al., 1977; Satter \& Roffler, 1977). Meissner et al. (1993) found that a dietary N content of $2.5 \% \mathrm{~N}$ corresponds with a rumen $\mathrm{NH}_{3}$ concentration of $20 \mathrm{mg} \mathrm{NH} / 100 \mathrm{ml}$.

There were no differences in in vivo digestible organic matter between treatments. Wilman (1970, 1975) reported that level of $\mathrm{N}$ fertilization had little effect on the in vitro DM digestibility of Italian ryegrass. Similarly, Deinum et al. (1968) and Hunt (1973) did not find any clear effect of $\mathrm{N}$ fertilization on in vivo digestibility of grasses.

A quadratic relationship $(\mathrm{P}=0.034)$ was found between $\% \mathrm{~N}$ in ryegrass and the $\mathrm{DM}$ intake of 12 month-old lambs (Table 2). At a pasture concentration of 3.8\% $\mathrm{N}$ this equation predicts a maximum DM intake of $1642 \pm 37.6 \mathrm{~g} / \mathrm{day}$. The data illustrate the negative effect of high concentrations of $\mathrm{N}$ in ryegrass on intake. A quadratic relationship $(\mathrm{P}=0.08)$ for $\% \mathrm{~N}$ in ryegrass and the $\mathrm{ADG}(\mathrm{g} /$ day) of 12 -month-old lambs predicts a maximum ADG of $102.7 \pm 12.2 \mathrm{~g}$ /day when the $\mathrm{N}$ content in ryegrass is $3.8 \%$ (Table 2). Dry matter intake and $\mathrm{ADG}$ were found to peak at $3.8 \% \mathrm{~N}(23.7 \% \mathrm{CP})$ in the pasture.

Table 2 The relationship between $\% \mathrm{~N}$ in ryegrass herbage (x) and dry matter intake and ADG of 12-monthold and weaner lambs over two seasons

\begin{tabular}{|c|c|c|c|c|}
\hline Regression & $\mathrm{N}$ & $S_{y . x}$ & $\mathrm{R}^{2}$ & $\mathrm{P}$ \\
\hline \multicolumn{5}{|l|}{ 12-month-old lambs: Dry matter intake (y) } \\
\hline$=-12397( \pm 6197)+7502( \pm 3338) x-1002( \pm 448) x^{2}$ & 29 & 137.3 & 0.098 & 0.034 \\
\hline \multicolumn{5}{|l|}{ 12-month-old lambs: ADG (y) } \\
\hline$=-3833( \pm 2004)+2041( \pm 1080) x-264( \pm 145) x^{2}$ & 29 & 44.4 & 0.175 & 0.08 \\
\hline \multicolumn{5}{|l|}{ Weaner lambs: Dry matter intake (y) } \\
\hline$=2209( \pm 322)-310.1( \pm 93.0) \mathrm{x}$ & 29 & 301.7 & 0.260 & 0.002 \\
\hline \multicolumn{5}{|l|}{ Weaner lambs: ADG (y) } \\
\hline$=-522( \pm 232)+434( \pm 142) x-71( \pm 21.1) x^{2}$ & 29 & 39.5 & 0.415 & 0.002 \\
\hline
\end{tabular}

The ADG of weaner lambs varied from 88 to $124 \mathrm{~g} /$ day over the 10-week feeding period (Table 3 ), which is unsatisfactory for the production of slaughter lambs. Grazing trials showed similar variation in lamb growth, and the equation of De Villiers et al. (1995) predicted an ADG of $167 \mathrm{~g} /$ day for a $25 \mathrm{~kg}$ weaner lamb grazing ryegrass. A negative linear relationship $(\mathrm{P}=0.002)$ was found between $\% \mathrm{~N}$ in pasture and $\mathrm{DM}$ intake (Table 2). The regression equation predicts a maximum DM intake of $1434 \pm 101 \mathrm{~g} /$ day with herbage containing $2.5 \% \mathrm{~N}$. A quadratic regression equation $(\mathrm{P}=0.002)$ describing the relationship between $\% \mathrm{~N}$ in pasture and ADG predicts a maximum ADG of $140 \pm 10.1 \mathrm{~g}$ /day when weaned lambs consume ryegrass 
pastures containing $\mathrm{N}$ concentrations of $3.0 \%(18.75 \% \mathrm{CP})$. Wool growth and fibre diameter were not influenced by the level of fertilization in either age group.

Table 3 The performance of 12-month-old and weaner lambs offered ryegrass subject to different $\mathrm{N}$ fertilization levels over two seasons

\begin{tabular}{|c|c|c|c|c|c|}
\hline & \multirow[b]{2}{*}{$\begin{array}{l}\text { Low } \\
(100 \text { or } 200 \mathrm{~kg} \mathrm{~N} / \mathrm{ha})\end{array}$} & \multicolumn{3}{|c|}{$\mathrm{N}$-fertilization level } & \multirow[b]{2}{*}{$\mathrm{P}$} \\
\hline & & $\begin{array}{l}\text { Medium } \\
(400 \mathrm{~kg} \mathrm{~N} / \mathrm{ha})\end{array}$ & $\begin{array}{l}\text { High } \\
(600 \text { or } 800 \mathrm{~kg} \mathrm{~N} / \mathrm{ha})\end{array}$ & s.e.m. & \\
\hline \multicolumn{6}{|c|}{$\begin{array}{l}\text { April - July } \\
\text { 12-month-old lambs: }\end{array}$} \\
\hline ADG (g/day) & 69 & 82 & 102 & 8.67 & 0.31 \\
\hline $\begin{array}{l}\text { Clean wool yield } \\
\left(\mathrm{g} / 100 \mathrm{~cm}^{2}\right)\end{array}$ & 4.35 & 4.37 & 4.20 & 0.171 & 0.90 \\
\hline $\begin{array}{l}\text { Wool fibre } \\
\text { diameter (ìm) }\end{array}$ & 22.4 & 22.2 & 22.5 & 0.26 & 0.88 \\
\hline \multicolumn{6}{|c|}{$\begin{array}{l}\text { August - November } \\
\text { Weaner lambs: }\end{array}$} \\
\hline ADG (g/day) & 108 & 124 & 88 & 9.33 & 0.30 \\
\hline $\begin{array}{l}\text { Clean wool yield } \\
\left(\mathrm{g} / 100 \mathrm{~cm}^{2}\right)\end{array}$ & 4.01 & 4.50 & 4.25 & 0.201 & 0.62 \\
\hline $\begin{array}{l}\text { Wool fibre } \\
\text { diameter (ìm) }\end{array}$ & 22.2 & 23.1 & 21.7 & 0.452 & 0.42 \\
\hline
\end{tabular}

During the second season, ryegrass fed to the 4-month-old lambs contained $\mathrm{NO}_{3}-\mathrm{N}$ concentrations of between 0.385 and $0.623 \%$. The relationship between $\mathrm{NO}_{3}-\mathrm{N}(\mathrm{x})$ content of pasture and $\mathrm{ADG}(\mathrm{y})$ was:

$y=160.1( \pm 23.0)-161.8( \pm 61.0) x\left(S_{y \cdot x}=27.1 ; r^{2}=54.7 ; P=0.06 ; n=5\right)$.

The regression equation describing the negative relationship between the $\mathrm{NO}_{3}-\mathrm{N}$ concentration of pasture (x) and DM intake (y) of weaner lambs during the second season was:

$\mathrm{y}=1585( \pm 201)-1308( \pm 532) x\left(S_{y \cdot x}=236.3 ; r^{2}=50.2 ; P=0.07 ; n=5\right)$.

Both these regression equations illustrate the negative effect of $\mathrm{NO}_{3}-\mathrm{N}$ on $\mathrm{DM}$ intake and growth rates of lambs.

\section{Conclusions}

Attempts to induce large differences in the chemical composition of Italian ryegrass through the application of different $\mathrm{N}$ fertilization levels were only partially successful. The regression equations derived in this study illustrate the negative effect of $\mathrm{N}$ and $\mathrm{NO}_{3}-\mathrm{N}$ concentrations in Italian ryegrass on DM intake and growth rate of weaner and 12-month-old lambs. From regression equations it is predicted that ADG will peak at $102.7 \pm 12.2 \mathrm{~g} /$ day for 12 -month-old lambs consuming ryegrass with $3.8 \% \mathrm{~N}(23.7 \% \mathrm{CP})$ in the pasture. Similarly, at 3.0\% N (18.7\% CP) ADG peaked at $140 \pm 10.1 \mathrm{~g} /$ day for weaned lambs. These results complement the results of Eckard (1990) which indicate that the DM yield of Italian ryegrass approaches a maximum when herbage $\mathrm{N}$ concentrations are between 3.2 and $3.5 \%$ (20 and 22\% $\mathrm{CP}$ ), and that fertilization levels above $350 \mathrm{~kg} \mathrm{~N} / \mathrm{ha} / \mathrm{yr}$ are in excess of the growth requirements of Italian ryegrass (Eckard, 1989).

\section{Acknowledgements}

The authors thank C. Stevens for the statistical analysis. W. Botha, G. Parker, S. Morning, J. Marais, and staff of the Sheep Section and Metabolism Building at Cedara are thanked for the field work and digestibility trials. 


\section{References}

Aii, T. \& Stobbs, T.H., 1980. Solubility of the protein of tropical pasture species and the rate of its digestion in the rumen. Anim. Feed Sci. Tech. 5, 183 - 192.

ARC., 1985. The nutrient requirements of ruminant livestock. Commonwealth Agricultural Bureaux. Farnham Royal, England.

AOAC., 1980. Official methods of analysis (11 ${ }^{\text {th }}$ Ed.). Association of official analytical chemists. Washington. D.C.

Barker, A.V., 1974. Nitrate determinations in soil, water and plants. Research Bulletin no. 611. Massachusetts Agricultural Experimental Station. 22.

Beever, D.E. \& Siddons, R.C., 1986. Digestion and metabolism in the grazing ruminant. In: Control of digestion and metabolism in ruminants. Eds. Milligan, L.P., Grovum, W.L. \& Dobson, A.A. Prentice Hall, Englewood Cliffs, N.J. pp. 479.

Bredon, R.M., Juko, C.D. \& Marshall, B., 1961. The nutrition of Zebu cattle. Part III. Digestibility techniques: investigation of the effects of combination of dry faeces, length of digestibility trials and number of animals required. J. Agric. Sci. Camb. 56, 99-103.

Coombe, N.B. \& Hood, A.E.M., 1980. Fertilizer-nitrogen: effects on dairy cow health and performance. Fertil. Res. 1, 157 - 176.

Deinum, B. \& Simba, L., 1980. Nitrate content of herbage in relation to nitrogen fertilization and management. The role of nitrogen in intensive grassland production. Proc. Int. Symp. Eur. Grassland Fed. Pudoc, Wageningen.

Deinum, B., Van Es, A.J.H. \& Van Soest, 1968. Climate, nitrogen and grass. 2. The influence of light intensity, temperature and nitrogen on in vivo digestibility of grass and prediction of these effects from some chemical procedures. Neth. J. Agric. Sci. 16, 217 - 223.

De Villiers, J.F., Dugmore, T.J. \& Botha, W.A., 1995. The relationship between pre- and post-weaning performance of lambs on Italian ryegrass. S. Afr. J. Anim. Sci. 25, $16-20$.

Dickson, I.A. \& Macpherson, A., 1976. The effects on ewes and lambs of grazing pasture containing differing levels of nitrate-nitrogen. J. Br. Grassld. Soc. 31, 129 - 134.

Eckard, R.J., 1986. The nitrogen nutrition of Italian ryegrass (Lolium multiflorum). MSc (Agric) thesis. University of Natal, South Africa.

Eckard, R.J., 1989. The response of Italian ryegrass to applied nitrogen content in the Natal Midlands. J. Grassl. Soc. South Afr. 6, 19 - 22.

Eckard, R.J., 1990. The relationship between the nitrogen and nitrate content and nitrate toxicity potential of Lolium multiflorum. J. Grassl. Soc. South Afr. 7, 174 - 178.

Genstat, 1993. Genstat 5 Committee of the Statistics Department, Rothamsted Experimental Station. Oxford, Claredon Press.

Hibbit, K.G., 1984. Effect of protein on the health of dairy cows. In: Recent advances in animal nutrition. Eds. Haresign, W. \& Cole, D.J.A., Butterworths, London. pp. 189.

Holmes, J.C. \& Lang, R.W., 1963. Effects of fertilizer nitrogen and herbage dry matter content on herbage intake and digestibility in bullocks. Anim. Prod. 5, 17 - 26.

Holst, D.O., 1973. Holst filtration apparatus for Van Soest detergent fibre analyses. L. AOAC. 56, 1352.

Hunt, V., 1973. Studies of response to fertilizer nitrogen. J. Br. Grassld. Soc. 28, 171 - 180.

Marais, J.P., 1985. Effect of nitrate upon the digestibility of kikuyu grass (Pennisetum clandestinum). PhD (Agric.) thesis. University of Natal, South Africa

Mehrez, A.Z., Orskov, E.R. \& McDonald, I., 1977. Rates of fermentation in relation to ammonia concentration. Br. J. Nutr. 38, 437 - 443.

Meissner, H.H., du Preez, Mariana, M., Enslin, A.D. \& Spreeth, E.B., 1992. Utilization of Lolium multiflorum by sheep. 1. Influence of dry matter content and correlated factors on voluntary intake. J. Grassl. Soc. South. Afr. 9, 11 - 17.

Meissner, H.H., Smuts, M., Van Niekerk, W.A., Acheampong-Boateng, O., 1993. Rumen ammonia concentrations, and non-ammonia nitrogen passage to and apparent absorption from the small intestine of sheep ingesting subtropical, temperate, and tannin-containing forages. S. Afr. J. Anim. Sci. 23, 92 - 97.

Orion Research Inc., 1979. Instruction manual; nitrate electrode. Orion Research Inc., Massachusetts, U.S.A.

Phipps, R.H., 1975. The effects on dairy cows of grazing pasture containing high levels of nitrate-nitrogen. J. Br. Grassld. Soc. 30, 45 - 49.

Satter, L.D. \& Roffler, R.E., 1977. Influence of nitrogen and carbohydrate inputs on rumen fermentation. In: 
Recent advances in animal nutrition. Eds. Haresign, W. \& Lewis, D., Butterworths, London.

Statgraphics, 1988. Statistical Graphic System. Statistical Graphic Corporation Inc., Rockville, Maryland.

Thomson, J.W., Yu, Y., Middleton, T. \& Stallings, C., 1982. In: Protein requirements for cattle. Ed. Owens, F.N., Oklahoma State University, Stillwater, pp 67.

Van der Merwe, B.J., 1993. The rumen degradation of nitrogen fractions in Italian ryegrass (Lolium multiflorum) by lactating dairy cows. MSc (Agric.) thesis. University of Natal, South Africa.

Van Soest, P.J. \& Robertson, J.B., 1980. Systems of analysis for evaluating fibrous feeds. In: Standardization of analytical methodology for feeds. Eds. Pidgen, W.J., Balch, C.C. \& Graham, M. Proceedings of a workshop, Ottawa, Canada. pp. 49.

Waghorn, G.C. \& Barry, T.N., 1987. Pasture as a nutrient source. In: Livestock feeding on pasture. Ed. Nico, A.M. N.Z. Soc. of Anim. Prod. Occasional Publication No. 10, pp. 21.

Weatherburn, M.W., 1967. Phenol-hypochlorite reaction for determination of ammonia. Analyt. Chem. 39, $971-974$.

Wilson, J.R., 1981. Environmental and nutritional factors affecting herbage quality. In: Nutritional limits to animal production from pastures. Ed. Hacker, J.B. Commonwealth Agric. Bureaux, Farnham Royal, U.K. pp. 111.

Wilman, D., 1970. The effect of nitrogenous fertilizer on the rate of growth of Italian ryegrass. 3. Growth up to ten weeks. J. Br. Grassld. Soc. 25, 242 - 245.

Wilman, D., 1975. Nitrogen and Italian ryegrass. 2. Growth up to 14 weeks: dry matter yield and digestibility. J. Br. Grassld. Soc. 30, 141 - 147. 